\title{
The effect of organic selenium in feeding of ewes in late pregnancy on selenium transfer to progeny
}

\author{
Sibel Erdoğan ${ }^{1 *}$, Filiz Karadaş ${ }^{1}$, Ayhan Yılmaz $^{2}$, Serhat Karaca ${ }^{1}$ \\ ${ }^{1}$ Yuzuncu Yil University, Faculty of Agriculture, Department of Animal Science, Van, Turkey. \\ ${ }^{2}$ Siirt University, Department of Animal Science, Siirt, Turkey.
}

\begin{abstract}
The objective of this study was to determine the effect of supplemented organic selenium at different levels to concentrate feed of Norduz ewes in late pregnancy on maternal serum, placenta, colostrum, and offspring serum concentrations. This study was conducted using two-year-old 35 Norduz ewes. Ewes were randomly assigned to one of three dietary treatments for 57 days prepartum and at the seven days postpartum. Group 1 was fed a standard pregnant sheep concentrate basal diet without any additional Se supplement (control). Experiment groups were fed diets supplemented with $0.150 \mathrm{mg} / \mathrm{kg}, 0.300 \mathrm{mg} / \mathrm{kg}$, and $0.450 \mathrm{mg} / \mathrm{kg}$ organic selenium to the same basal diet. Results showed that addition of selenium to gestating ewe diets increased Se in serum after one week of feeding. Ewes supplemented with $0.300 \mathrm{and} 0.450 \mathrm{mg} / \mathrm{kg}$ Se had increased placenta, serum, and colostrum Se levels compared with those fed the control diet $(\mathrm{P}<0.05)$. There was a strong positive correlation between placental and serum Se concentration in ewes. Colostrum Se increased linearly with dietary Se in the treatment groups. At birth, lamb serum Se ranged from $48.96 \mathrm{ng} / \mathrm{mL}$ to $195.52 \mathrm{ng} / \mathrm{mL}$ and was affected by the Se concentration of the ewe diets, which indicated placenta transfer of selenium from the dam. As selenium level increased in basal diet, an upward trend was observed in maternal free thyroxine concentration. Likewise, serum free triiodothyronine, free thyroxine, and immunoglobulin $\mathrm{G}$ concentrations of lambs from the three treatment groups were significantly greater than of the control lambs. As a result, selenium supplementation was important for maintaining Se and immunoglobulin G concentration in placenta, serum, and colostrum in ewes.
\end{abstract}

Key Words: ewe, organic selenium, pregnancy, progeny

\section{Introduction}

Selenium (Se) is an essential trace mineral in animals that is required to maintain normal physiological functions and provides a significant dietary source of antioxidant defenses (Sordillo, 2013). It is obtained by animals as components of the diet and its transplacental transfer is an important factor for their offspring. (Moeini et al., 2011).

Selenium deficiencies play a role in numerous economically important livestock diseases, problems that include impaired fertility, abortion, retained placenta, and neonatal weakness (Spears, 2011). Mortality and economic losses occur in the Eastern Anatolia region of Turkey because of mineral deficiency and imbalances in

Received: August 5, 2016

Accepted: November 6, 2016

*Corresponding author: serdogan@yyu.edu.tr

http://dx.doi.org/10.1590/S1806-92902017000200010

How to cite: Erdoğan, S.; Karadaş, F.; Yılmaz, A. and Karaca, S. 2017. The effect of organic selenium in feeding of ewes in late pregnancy on selenium transfer to progeny. Revista Brasileira de Zootecnia 46(2):147-155.

Copyright (C) 2017 Sociedade Brasileira de Zootecnia. This is an Open Access article distributed under the terms of the Creative Commons Attribution License (http://creativecommons.org/licenses/by/4.0/), which permits unrestricted use, distribution, and reproduction in any medium, provided the original work is properly cited. lambs in particular (Kozat et al., 2007). Pastures in Turkey are typically poor in selenium (Karadaş, 2014). Deaths caused by Se deficiency are noteworthy; according to the study of Pilarczyk et al. (2004), lamb losses in experimental Se supplemented group were lower $(9.2 \%)$ than the control group (12.1\%).

In some cases, both macro and trace elements have to be added to the diet to prevent deficiencies in highly productive animals (Fisher, 2008). Although all feeds have a listed permitted level of $0.3 \mathrm{mg} / \mathrm{kg}$, the level of $\mathrm{Se}$ in diets is $0.4-0.5 \mathrm{mg} / \mathrm{kg}$ (Rutigliano et al., 2006). Deficiency may be prevented by adding $0.10 \mathrm{ppm}$ Se to sheep diets. The toxicity of organic Se is at least three times less than inorganic Se and organic Se is more protective than inorganic Se, as it is incorporated into tissue reserves (Lyons et al., 2007).

The amount of nutrients transferred to the offspring depends on maternal nutrient status and the efficiency of the transplacental and mammary transport mechanisms. The passage of trace elements and other nutrients through the placenta is required for fetal nutrition and growth as well as for maternal and fetal physiological functions during gestation. Provision of Se to the mother during pregnancy is an effective method to meet Se requirements in the newborn, 
as it efficiently passes through the placental barrier into fetal tissues and is also transferred into colostrum and milk (Rock et al., 2001; Stewart et al., 2012). A close relationship has been detected between offspring serum Se and maternal levels after feeding with $\mathrm{Se}$, once the offspring obtains this nutrient via the placenta before birth (Hefnawy et al., 2014). Hefnawy et al. (2007) suggested that the allantoic sac plays an important role in homeostasis of nutrients and metabolites and Se concentration of amniotic and allantoic fluids may be used as an indicator of Se status in the fetus throughout gestation. In this sense, determining the motheroffspring relationship in terms of Se is important for animal health. The objective of this study was to evaluate the effects of organic Se in feeding of ewes of late pregnancy on progeny selenium transfer.

\section{Material and Methods}

The protocol for the animal experiment was reviewed and approved by Animal Researches Local Ethic Committee (YUHADYEK, case no. 2015/02) of the Yüzüncü Yil University.

Thirty-five pregnant Norduz ewes were selected after ultrasound examination, approximately at 90 days of pregnancy. The ewes were two years of age with an average body weight of $40 \pm 0.5 \mathrm{~kg}$. These ewes were randomly divided into four treatment groups, as follows: group 1 was a standard pregnant sheep concentrate basal diet without any additional Se supplement; the low-Se control diet was prepared to the meet the requirements given in NRC (2007); the other three experimental diets were prepared by adding Se (Sel-plex; $2000 \mathrm{Se} \mathrm{mg} / \mathrm{kg}$ ) as the organic selenium source at three different levels: 0.150, 0.300, and $0.450 \mathrm{mg} / \mathrm{kg}$ to the same basal diet.

The raw materials used in experiment rations (barley, wheat bran, and cottonseed meal) were obtained from a private feed factory. Organic Se (Sel-plex) contained 2000$2400 \mathrm{mg} \mathrm{Se} / \mathrm{kg}$ (97-99\% of organic Se). Sel-plex consists mainly of selenomethionine $(63 \%)$ and low-molecular weight selenium components (34-36\%) (Alltech, USA). Sel-plex was added to the feed; selenium doses were mixed with $2 \mathrm{~kg}$ feed to obtain a homogenous mixture of Sel-plex, which was then added to the experiment diets and mixed to obtain homogeneity.

In this study, four experimental diet groups were used (Table 1). Ewes in the four groups were homogeneous for age and weight and were fed alfalfa hay and concentrate providing $2600 \mathrm{kcal} / \mathrm{kg}$ metabolizable energy and $13.13 \%$ crude protein, respectively, according to their requirements and body weight (NRC, 2007).
Ewes were fed the allocated diets from 50 days prepartum and seven days postpartum was maintained on their treatments for lambing. Birth of all the ewes was observed. Lambs were immediately removed from their dams before suckling and were cared for in a separate pen. Lambs were dried with a towel and time of birth and birth weight were recorded. A total of 38 lambs were born; eight of these lambs were in control group and the others were separated into the three experimental groups, 10 lambs in each.

The last stage of lambing includes the expulsion of the placenta, which occurs 45 to $60 \mathrm{~min}$ after the delivery of the last lamb. When the placenta was discharged, it was cleaned with double-distilled water. A section of $10 \mathrm{~cm}^{2}$ was taken from the placentas. These sections were brought to the laboratory in physiological saline; then they were removed from the saline solution, put in vacuum bags, and kept at $-20^{\circ} \mathrm{C}$. Prior to analysis, the placenta samples were dried in oven at $105^{\circ} \mathrm{C}\left( \pm 2{ }^{\circ} \mathrm{C}\right)$, ground in a porcelain mortar, and stored in airtight vessels until $\mathrm{Se}$ analyses (Alonso et al., 2005).

A total weight of $0.5 \mathrm{~g}$ of dried placenta sample was taken and $5 \mathrm{~mL}$ of nitric acid and $2 \mathrm{~mL}$ perchloric acid were added directly into the tube. This was hydrolyzed in Kjeldahl tubes with the temperature gradually rising at short intervals. The samples were filtered through Whatman 4.01 and diluted with $10 \mathrm{~mL}$ double-distilled water. Inductively coupled plasma optical emission spectrometry (ICP-OES)

Table 1 - Diet composition (as fed) and nutrient matter composition (dry matter basis) for ewes in the last third of pregnancy ${ }^{1}$

\begin{tabular}{lc}
\hline & Concentrate feed $(\mathrm{kg})$ \\
\hline Ingredient & \\
Barley & 600.00 \\
Wheat & 100.00 \\
Wheat bran & 100.00 \\
Cottonseed meal & 170.00 \\
Ground limestone & 10.00 \\
Vitamin-mineral mix & \\
Salt & 5.00 \\
Total & 10.00 \\
Nutrient matters composition $(\%)$ & 1000.00 \\
Dry matter & \\
Organic matter & 92.24 \\
Crude protein & 85.61 \\
Crude fat & 13.13 \\
Neutral detergent fiber & 2.07 \\
Acid detergent fiber & 30.06 \\
Metabolizable energy & 10.85 \\
\hline
\end{tabular}

${ }^{1}$ Selenium content of control, $0.150,0.300$, and $0.450 \mathrm{mg} / \mathrm{kg}$ Se diets and alfalfa hay was found $0.1,0.27,0.38,0.53$, and $0.06 \mathrm{mg} / \mathrm{kg}$, respectively.

${ }^{2}$ Vitamin-mineral premix contains per kg: cobalt, $2 \mathrm{mg}$; copper, $30 \mathrm{mg}$; iron, $25 \mathrm{mg}$; manganese, $100 \mathrm{mg}$; iodine $5 \mathrm{mg}$; zinc, $100 \mathrm{mg}$; vitamin A, $10 \mathrm{IU}$; vitamin D3, $2.5 \mathrm{IU}$; vitamin E ( $\alpha$-tocopherol), 50 IU. 
was used for determining the Se concentration (Norheim and Haugen, 1986).

Blood samples were collected from gestating ewes (on the 7th and 21st days of the experiment and at parturition) and from lambs (immediately after birth and at seven days after birth) in 10-mL samples from the vena jugularis into tubes without anticoagulant and centrifuged at 4000 $\mathrm{rpm}$ for $10 \mathrm{~min}$. Serum was separated and kept at $-80^{\circ} \mathrm{C}$ until analyses to determine $\mathrm{Se}$, free triiodothyronine (fT3), free thyroxine (fT4), and immunoglobulin G (IgG) concentrations. Serum IgG was determined through competitive enzyme immunoassay technique using Abbott Micro-ELISA with ELISA commercial test kits (Cusabio, sheep immunoglobulin G ELISA kit, catalogue number CSB-E14400Sh) in duplicate.

The serum Se levels were determined using hydride generation and ICP-OES (Norheim and Haugen, 1986). The concentrations of serum fT3 and fT4 were analyzed using a high-performance immunoassay analyzer with paramagnetic microparticle and chemiluminescent detection (Abbott Architect 1600, Abbott Diagnostics) (Quinn, 2005).

Lambs were given access to suckle their mothers half an hour after the birth. Ewes were milked immediately after suckling of lambs and a $50 \mathrm{~mL}$ sample of colostrum was collected and frozen, placed on dry ice, and shipped to the respective laboratory for Se analysis. Colostrum samples were kept at $-80^{\circ} \mathrm{C}$ until Se analyses were done. The Se level in colostrum was determined by using hydride generation and ICP-OES (Norheim and Haugen, 1986).

Feed samples were taken weekly from the concentrate feed and alfalfa hay used throughout the experiment. Feed samples were ground through a 1-mm screen and subjected to determination of Se level and nutrient matter analysis.

Crude protein was determined by Kjeldahl, procedure 928.08 (AOAC, 1990). Ether extract was determined using petroleum ether in an ANKOM XT15 (AOCS Official Procedure Am 5-04) (ANKOM, 2008). Neutral detergent fiber and acid detergent fiber were determined using the method described by Van Soest et al. (1991). The neutral detergent fiber analysis used sodium sulfite in the neutral detergent solution. The level of Se in feeds was determined using hydride generation and ICP-OES (procedure 968.08) (AOAC, 1990).

Data were analyzed by SAS (Statistical Analysis System, version 9.4) using the general linear model. Duncan's multiple comparison procedure was employed to determine the differences among the groups. Results were presented as least square means and standard errors of the means. The correlation between the obtained results was tested with a Pearson correlation test.
The differences among treatment groups were estimated using the following model:

$$
\mathrm{Y}_{i j}=\mu+\alpha_{i}+e_{i j},
$$

in which $\mathrm{Y}_{i j}=$ dependent variable; $\mu$ = overall mean; $\alpha_{i}=$ the fixed effect of organic Se level $(i=0.150,0.300$, and $0.450 \mathrm{mg} / \mathrm{kg}$ ); and $e_{i j}=$ experimental error assumed to be NID with $\left(0, \sigma^{2} e\right)$. Serum selenium concentrations of ewes at different periods of pregnancy and lambs were analyzed by the GLM method using the following equation:

$$
\mathrm{Y}_{i j k}=\mu+\alpha_{i}+\beta_{j}+e_{i j k},
$$

in which $\mathrm{Y}_{i j k}=$ dependent variable; $\mu=$ overall mean; $\alpha_{i}=$ the fixed effect of organic Se level $(i=0.150,0.300$, and $0.450 \mathrm{mg} / \mathrm{kg}) ; \beta_{j}=$ effect of sampling time; and $e_{i j k}=$ experimental error assumed to be NID with $\left(0, \sigma^{2} e\right)$.

\section{Results}

A significant increase in serum Se concentration of ewes was determined regardless of Se intake (Figure 1). Serum Se concentrations of ewes in the first week was higher in ewes of the three experimental groups compared with the control group $(\mathrm{P}<0.05)$. Concentrations of $\mathrm{Se}$ in ewe serum were affected by dietary Se levels. Ewes from the treatment with $0.450 \mathrm{mg} / \mathrm{kg}$ Se had the highest serum Se concentrations at the $3 \mathrm{rd}$ week and parturition compared with the other groups $(\mathrm{P}<0.05)$.

In the present study, the addition of organic $\mathrm{Se}$ in feed to ewes in late pregnancy increased serum, placenta, and colostrum Se concentrations compared with ewes in control group (Table 2 and Figure 1). Serum concentrations

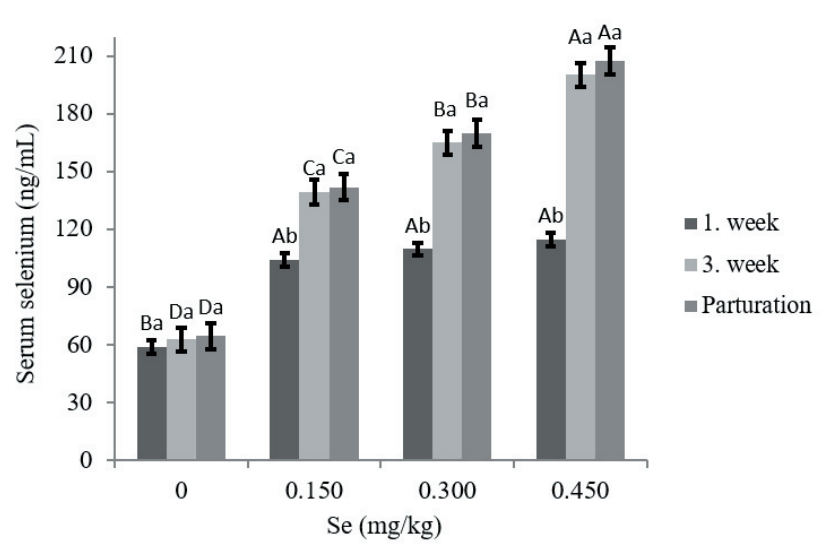

LSmean - least square mean; SEM - standard error of the mean.

A, B, C, D - Means are significantly different between serum selenium concentrations at different periods in control $(0), 0.150,0.300$, and $0.450 \mathrm{mg} / \mathrm{kg}$ Se groups $(\mathrm{P}<0.05)$.

$\mathrm{a}, \mathrm{b}$ - There is a statistically significant difference in the same group $(\mathrm{P}<0.05)$.

Figure 1 - Effect of organic selenium supplementation on serum selenium concentration (LSmean \pm SEM) of ewes at different periods of pregnancy. 
were 64.53, 141.73, 169.83, and 207.45 ng/mL $(\mathrm{P}<0.05)$, respectively, for control and $0.150,0.300$, and $0.450 \mathrm{mg} / \mathrm{kg}$ Se treatment groups (Figure 2).

Placenta and colostrum Se concentrations in control ewes were 15.97 and $214.78 \mathrm{ng} / \mathrm{mL}$, respectively (Table 2). Selenium supplementation significantly and linearly increased Se concentration in placenta and colostrum $(\mathrm{P}<0.05)$ compared with the control group. It was noted that $\mathrm{Se}$ in the placenta $(\mathrm{r}=0.845, \mathrm{P}<0.01)$ and colostrum $(\mathrm{r}=0.681, \mathrm{P}<0.01)$ were positively correlated with the Se concentration in maternal serum. There was no significant accumulation seen for the control or $0.150 \mathrm{mg} / \mathrm{kg}$ Se treatments. In the current study, when dietary Se was increased from $0.150 \mathrm{mg} / \mathrm{kg}$ up to $0.450 \mathrm{mg} / \mathrm{kg}$, colostrum Se increased from 258.43 to $424.45 \mathrm{ng} / \mathrm{mL}$, respectively $(\mathrm{P}<0.05)$. Organic Se had an insignificant effect on fT3 concentrations, whereas significant effect on $\mathrm{fT} 4$ concentration $(\mathrm{P}<0.05)$ (Table 3 ). As Se level increased in feed, an upward trend was manifested in fT4 concentration.

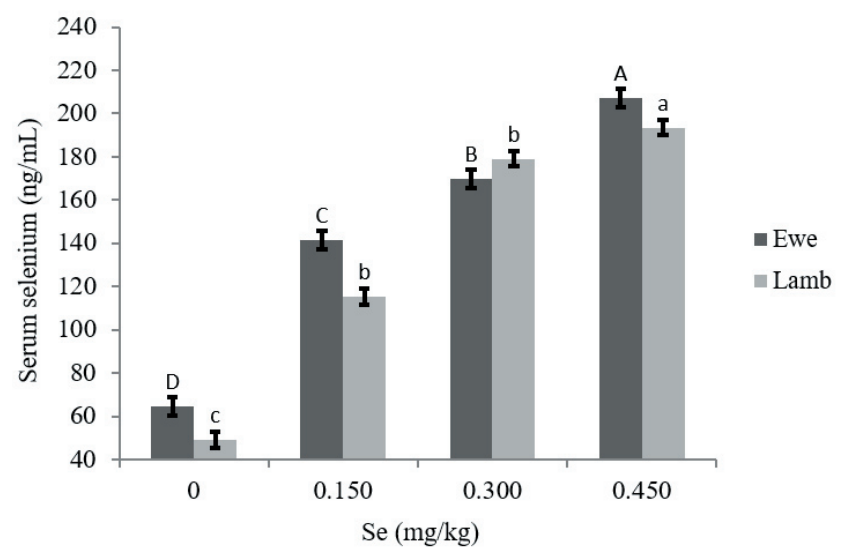

LSmean - least square mean; SEM - standard error of the mean.

A, B, C, D - Means are significantly different among control (0), 0.150, 0.300, and $0.450 \mathrm{mg} / \mathrm{kg}$ Se ewes $(\mathrm{P}<0.05)$.

$\mathrm{a}, \mathrm{b}, \mathrm{c}-$ Means are significantly different among control (0), 0.150, 0.300, and $0.450 \mathrm{mg} / \mathrm{kg}$ Se lambs $(\mathrm{P}<0.05)$.

Figure 2 - Serum selenium concentration (LSmean \pm SEM) of control and $0.150,0.300$, and $0.450 \mathrm{mg} / \mathrm{kg}$ Se treatment ewes and their lambs.

Table 2 - Mean placenta and colostrum selenium concentrations $(\mathrm{ng} / \mathrm{mL})$ of ewes fed with different levels of organic selenium supplementation

\begin{tabular}{lcccc}
\hline Treatment & $\mathrm{n}$ & Serum Se & Placenta Se & Colostrum Se \\
\hline Control & 8 & $64.53 \pm 4.06 \mathrm{~d}$ & $15.97 \pm 1.09 \mathrm{~d}$ & $214.78 \pm 18.53 \mathrm{~b}$ \\
$0.150 \mathrm{mg} / \mathrm{kg} \mathrm{Se}$ & 9 & $141.73 \pm 4.42 \mathrm{c}$ & $21.80 \pm 0.61 \mathrm{c}$ & $258.43 \pm 18.19 \mathrm{~b}$ \\
$0.300 \mathrm{mg} / \mathrm{kg} \mathrm{Se}$ & 9 & $169.83 \pm 7.90 \mathrm{~b}$ & $23.93 \pm 0.27 \mathrm{~b}$ & $399.51 \pm 13.36 \mathrm{a}$ \\
$0.450 \mathrm{mg} / \mathrm{kg} \mathrm{Se}$ & 9 & $207.45 \pm 8.86 \mathrm{a}$ & $32.50 \pm 0.20 \mathrm{a}$ & $424.45 \pm 26.22 \mathrm{a}$ \\
\hline
\end{tabular}

Values within a column in the same test with different letters are significantly different $(\mathrm{P}<0.05)$.
Lamb birth weight was not affected by treatment $(\mathrm{P}>0.05)$. The mean birth weight for control and 0.150, 0.300 , and $0.450 \mathrm{mg} / \mathrm{kg}$ Se treatment groups were $4.45 \pm 0.30$, $4.60 \pm 0.25,4.51 \pm 0.26$, and $4.69 \pm 0.20 \mathrm{~kg}$, respectively. At birth, lamb serum Se ranged from 48.96 to $195.52 \mathrm{ng} / \mathrm{mL}$ and was affected $(\mathrm{P}<0.05)$ (Figure 3 ) by the supplementation of Se in the ewe diets, which indicated placental transfer. There was a strong positive correlation between placenta $\mathrm{Se}$ concentration and levels in lamb serum $(\mathrm{r}=0.857 ; \mathrm{P}<0.01)$. Lamb thyroid hormone concentrations were influenced by Se supplementation (Table 4). Serum fT3 and fT4 in lambs

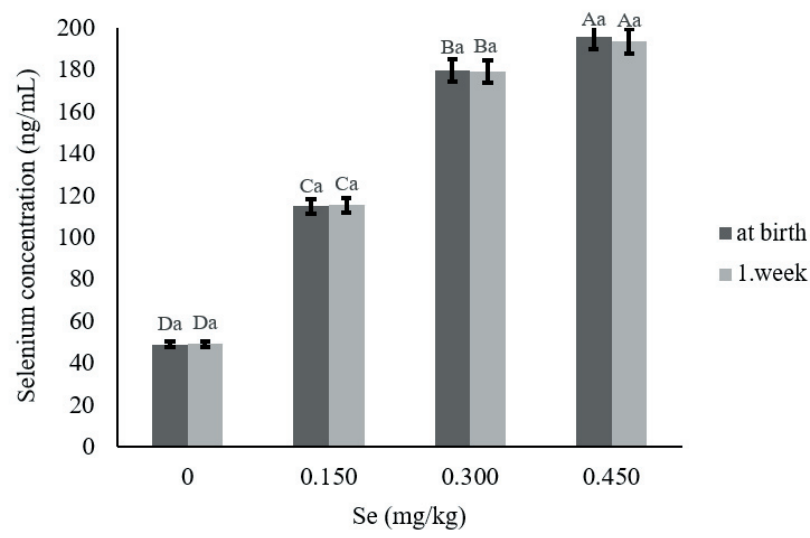

LSmean - least square mean; SEM - standard error of the mean.

A, B, C, D - Means within the groups with different letters differ significantly $(\mathrm{P}<0.05)$.

a, a - Means within the same group with different letters differ significantly $(\mathrm{P}>0.05)$.

Figure 3 - Serum selenium concentration (LSmean \pm SEM) of newborn lambs as related to organic selenium supplementation to diets of ewes in late pregnancy.

Table 3 - Serum free triiodothyronine $(\mathrm{pg} / \mathrm{mL})$ and free thyroxine (ng/dL) concentrations of ewes fed different levels of organic selenium supplementation

\begin{tabular}{lccc}
\hline Treatment & $\mathrm{n}$ & Free triiodothyronine & Free thyroxine \\
\hline Control & 8 & $2.72 \pm 0.15$ & $0.84 \pm 0.03 \mathrm{~b}$ \\
$0.150 \mathrm{mg} / \mathrm{kg} \mathrm{Se}$ & 9 & $2.39 \pm 0.09$ & $0.88 \pm 0.03 \mathrm{ab}$ \\
$0.300 \mathrm{mg} / \mathrm{kg} \mathrm{Se}$ & 9 & $2.50 \pm 0.09$ & $0.89 \pm 0.02 \mathrm{ab}$ \\
$0.450 \mathrm{mg} / \mathrm{kg} \mathrm{Se}$ & 9 & $2.46 \pm 0.08$ & $0.90 \pm 0.03 \mathrm{a}$ \\
\hline
\end{tabular}

Values within a column in the same test with different letters are significantly different $(\mathrm{P}<0.05)$.

Table 4 - Effect of organic selenium supplementation on free triiodothyronine $(\mathrm{pg} / \mathrm{mL})$ and free thyroxine $(\mathrm{ng} / \mathrm{dL})$ concentration of newborn lambs

\begin{tabular}{lccc}
\hline Treatment & $\mathrm{n}$ & Free triiodothyronine & Free thyroxine \\
\hline Control & 8 & $6.73 \pm 0.47 \mathrm{~b}$ & $1.54 \pm 0.09 \mathrm{~b}$ \\
$0.150 \mathrm{mg} / \mathrm{kg} \mathrm{Se}$ & 10 & $7.33 \pm 0.96 \mathrm{ab}$ & $1.66 \pm 0.08 \mathrm{ab}$ \\
$0.300 \mathrm{mg} / \mathrm{kg} \mathrm{Se}$ & 10 & $8.55 \pm 1.17 \mathrm{a}$ & $1.90 \pm 0.10 \mathrm{a}$ \\
$0.450 \mathrm{mg} / \mathrm{kg} \mathrm{Se}$ & 10 & $7.82 \pm 0.61 \mathrm{a}$ & $1.93 \pm 0.09 \mathrm{a}$ \\
\hline
\end{tabular}

Values within a column in the same test with different letters are significantly different $(\mathrm{P}<0.05)$. 
born from Se-supplemented ewes was higher $(\mathrm{P}<0.05)$ than in those from control ewes.

A significant increase in the content of immunoglobulin $\mathrm{G}$ in the serum of ewes was recorded in the last pregnancy regardless of Se intake. In the current study, lambs from Se-supplemented ewes had increased serum IgG concentrations compared with lambs from the control group ( $\mathrm{P}<0.05$; Figure 4). Moreover, there was a strong positive correlation between serum IgG concentration of ewes and that of lambs $(\mathrm{r}=0.725 ; \mathrm{P}<0.01)$.

\section{Discussion}

The purpose of this study was to evaluate the effects of organic Se and supplementation on efficiency of progeny transfer in ewes. The varying content regions of Se concentration in pastures confirm previous research in Turkey (Karadaş, 2014).

The optimal concentration of Se in the blood serum of ewes is $120-150 \mu \mathrm{g} / \mathrm{L}$ (Hefnawy et al., 2007), while values from $25-50 \mu \mathrm{g} / \mathrm{L}$ are considered deficient (Øvernes et al. (1985). In the present study, the concentration of Se in the blood serum of ewes was found optimal in the three groups $(141.73 ; 169.83 ; 207.45 \mathrm{ng} / \mathrm{mL})$ (Table 2). The Se level of ewes fed the control diet was lower than the $158.3 \mathrm{ng} / \mathrm{mL}$ during late-stage pregnancy reported by Hefnawy et al. (2007), $485 \mathrm{ng} / \mathrm{mL}$ reported by researchers from the Ukraine (P1larczyk et al., 2004), or the $90 \mathrm{ng} / \mathrm{mL}$ of USA sheep blood Se level (Coggins, 2006). Öncüler et al. (1996) reported that serum Se level of sheep and

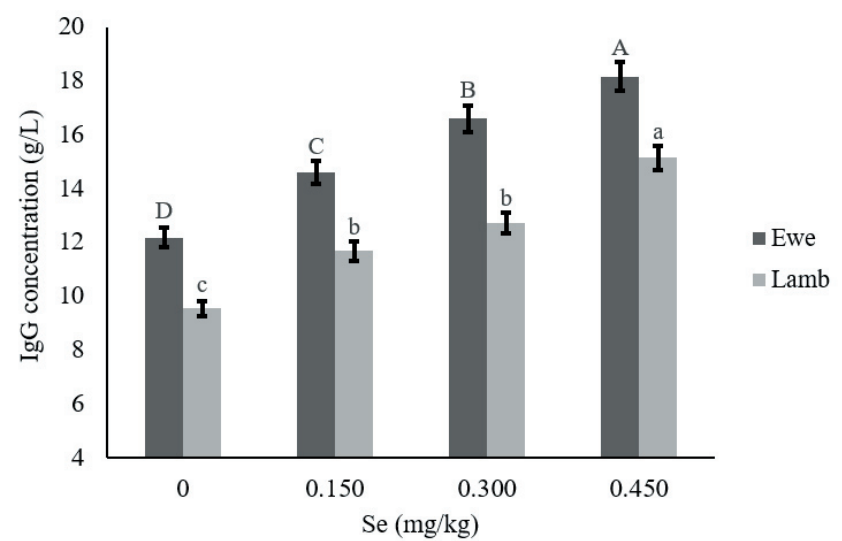

LSmean - least square mean; SEM - standard error of the mean

A, B, C, D - Means are significantly different among control (0), 0.150, 0.300, and $0.450 \mathrm{mg} / \mathrm{kg}$ Se treatment ewes $(\mathrm{P}<0.05)$.

$\mathrm{a}, \mathrm{b}, \mathrm{c}-$ Means are significantly different among control $(0), 0.150,0.300$, and $0.450 \mathrm{mg} / \mathrm{kg}$ Se treatment lambs $(\mathrm{P}<0.05)$.

Figure 4 - Effect of organic selenium supplementation on serum $\mathrm{IgG}$ concentration (LSmean $\pm \mathrm{SEM}$ ) of newborn lambs and ewes. cows was $100 \mathrm{ng} / \mathrm{mL}$ in all seasons from the north and southeast of Turkey, which was stated to be the physiology normal level. However, samples from Middle Anatolia taken during the winter showed that Se levels were low (51-75 ng/mL). Animals with less than $0.05 \mathrm{ppm}$ of whole blood Se were classified as deficient (Waldner et al., 1998). Serum Se concentrations during late pregnancy determined in control group in the present study indicate that sheep raised in this region had physiologically low, almost deficient Se concentrations. Similar results were reported by Kurt et al. (2001), who observed that blood Se levels of Akkaraman sheep in the Diyarbakır region (southeast of Anatolia) were 46-65 ng/mL. These results are similar to the findings reported by Kurt et al. (2001) in the current trial, although the results of these authors were higher than those seen in a Polish research, in which the serum Se level of sheep was $31 \mathrm{ng} / \mathrm{mL}$ (P1larczyk et al., 2004), or the Iranian trial with $28 \mathrm{ng} / \mathrm{mL}$ (Karimi-Poor et al., 2011), or the German trial, which showed $45 \mathrm{ng} / \mathrm{mL}$ (Humann-Ziehank et al., 2013).

Øvernes et al. (1985) reported that plasma Se concentration of sheep should be $150-350 \mathrm{ng} / \mathrm{mL}$, as white muscle disease is seen when it is below $100 \mathrm{ng} / \mathrm{mL}$. According to NRC (2007), sheep Se requirement ranges from 0.1 to $0.2 \mathrm{ppm}(100-200 \mathrm{ng} / \mathrm{mL})$ and to provide this level, supplemental Se is necessary. In the current study, dietary supplementation with Se produced 1.37, 1.49, and 2.04- fold increase in the total amount of Se in the serum, compared with the control diet. The results also agreed with Awawdeh and Talafha (2015), who reported that supplemental Se in the diet of ewes following birth in a four-week period increased Se concentration of milk, sheep tissues, and lamb blood. The current study results are similar to those reported by Abdelrahman and Kincaid (1995) and Davis et al. (2006), who observed that Se supplementation increased plasma Se content of ewes. The current data showed a high positive relationship between the concentration of Se in the serum of ewes and lambs $(\mathrm{r}=0.798 ; \mathrm{P}<0.01)$ (Figure 2). These results are parallel to those of Kincaid and Hodgson (1989) and Gunter et al. (2013), who reported a strong correlation $(r=0.74 ; r=0.78)$ between maternal and newborn serum Se concentrations.

Gabryszuk and Klewiec (2002) reported that Se injection (four weeks before the mating season and four weeks before lambing) was associated with a higher percentage of ewes in estrus, more lambs born per ewe, and higher lamb daily weight gain. Similarly, survival of lambs, live weight at birth, and weaning was increased by $\mathrm{Se}$ supplementation (Langlands et al., 1991a; Langlands et al., 1991b). In another study of Se/vitamin E supplementation 
in Se-deficient sheep, Hemingway (2003) obtained various positive responses, including increased lambing percentage, fewer barren ewes, and increased multiple births. Prepartum Se injection resulted in higher colostrum and milk Se (Cuesta et al., 1994). Administration of Se and vitamin $\mathrm{E}$ during pregnancy increased ewe blood Se concentrations (Awawdeh and Talafha, 2015). It has been suggested that Se deficiency in cattle could be prevented by parenteral administration of $50 \mathrm{mg}$ Se and $3000 \mathrm{mg}$ vitamin E on the 21st and 5th day before calving, respectively (Kolb and Seehawer, 2001).

Selenium transfer via placenta, colostrum, and milk could provide an important route for improvement of antioxidant intake and defense in newborn lambs. Ewes of the treatments with 0.300 and $0.450 \mathrm{mg} / \mathrm{kg}$ Se significantly improved colostrum and Se accumulation compared with ewes of $0.150 \mathrm{mg} / \mathrm{kg}$ Se and control treatments. Selenium status of newborn lambs has been reported to be closely correlated to Se status of their mothers (Hefnawy et al., 2007). Thus, transplacental transfer of Se is the primary source of $\mathrm{Se}$ in newborn lambs before ingestion of colostrum. In our study, transplacental transfer of Se from ewe to lamb was affected by the dose of organic Se. Nutrient transfer from dam to offspring occurs via two pathways: placental transfer and colostrum/milk ingestion (Hefnawy et al., 2014). Selenium placental transfer was demonstrated by De Toledo and Perry (1985) and Stewart et al. (2012) and fetal selenium concentrations have been shown to be greater (Stewart et al., 2012) than corresponding maternal selenium concentrations. Addition of Se to the maternal diet increased Se concentration in both serum and colostrum (Phipps et al., 2008; Slavik et al., 2008; Karren et al., 2010; Kachuca et al., 2013). Hefnawy and Tortoro-Perez (2010) explored the effects of addition of selenium in the diets of sheep before and after birth and concluded that prepartum addition of Se played on active role in maintaining optimal plasma selenium level, while postpartum addition of Se ensured the continuation of milk. Cuesta et al. (1995) explored the effects of high-dose prepartum injections of $\mathrm{Se}$ and vitamin $\mathrm{E}$ on milk and serum concentrations in ewes and reported that mean of Se concentrations in colostrums and milk ranged from 0.035 to $0.198 \mathrm{ppm}$ and from 0.016 to $0.027 \mathrm{ppm}$, respectively. In another study, Norton and McCarthy (1986) reported that colostrum Se concentration varied between 0.104 and $0.118 \mathrm{ppm}$ and colostrum Se from supplemented ewes was increased over unsupplemented controls. Selenium injection in pregnant heifers significantly increased concentrations of $\mathrm{Se}$ in colostrum (Moeini et al., 2011). Supplementary dietary Se increased concentration in ewe blood, lamb blood, and ewe milk at four weeks postpartum (Cuesta et al., 1995; Hefnawy et al., 2008; Awawdeh and Talafha, 2015). Increasing Se level in diet of gestating animals may prove beneficial to their offspring as it provides greater antioxidative protection through increased colostrum Se and can be linked to greater phagocytic and microbicidal activity (Wuryastuti et al., 1993).

Selenium is a trace element that is essential for normal thyroid hormone metabolism. Selenium is required for conversion of T4 into the more active T3 via the enzyme type 4 deiodinase (Hefnawy et al., 2014). In our experiment, a higher nutritional dosage of Se did not result in a significantly higher serum fT3 level. Beckett et al. (1989) reported that $10 \mu \mathrm{g} / \mathrm{kg}$ Se supplementation of rats did not change serum T3 and T4 levels, but $200 \mu \mathrm{g} / \mathrm{kg} \mathrm{Se}$ addition returned $\mathrm{T} 3$ and $\mathrm{T} 4$ concentration to normal levels. Selenium-deficient steers and heifers were characterized by decreased $\mathrm{T} 3$ and increased $\mathrm{T} 4$ serum concentration in comparison to Se supplemented diet (Arthur et al., 1992; Wichtel et al., 1996). Nazifi et al. (2008) and Konečný et al. (2015) stated that the plasma concentration of total T3 was reduced by iodine, whereas selenium treatment had no significant effect on plasma T3.

The lambs from treated ewes had higher serum Se concentrations compared with controls; this fact was in agreement with previous reports. Lamb serum Se concentrations were higher than the $>70 \mu \mathrm{g} / \mathrm{L}$ suggested as adequate by Davis et al. (2006). Jalilian et al (2012) reported that plasma Se concentrations were markedly increased in supplemented Sanjabi ewes and their lambs. Davis et al. (2006) reported that lamb plasma Se level was affected by the Se content of ewe diets and ranged from 74 to $775 \mu \mathrm{g} / \mathrm{L}$. Nevertheless, no lambs had plasma levels near or above $1400 \mu \mathrm{g} / \mathrm{L}$, which has been suggested as the level when signs of Se toxicosis appear in sheep (Davis et al., 2006). According to studies in cattle and sheep, various authors (Donald et al., 1994; Awadeh et al., 1998; Rock et al., 2001; Rowntree et al., 2004; Hefnawy et al., 2014) presented results that clearly demonstrate the importance of supplementation to maintain Se and T3 homeostasis in both pregnant ewes and their offspring. Rock et al. (2001) demonstrated this condition in pregnant ewes but $\mathrm{T} 3$ only presented a tendency to have higher levels in their lambs.

Serum IgG concentration increased significantly among groups at lambing. Immunoglobulin $\mathrm{G}$ of the blood serum of lambing ewes are their very important source for colostrums and newborn young. Serum IgG concentrations in lambs had a wide variation. When Se was supplemented 
in diet of sheep at the last $1 / 3$ of the pregnancy stage, the serum IgG concentration of their newborn lambs rose from $0.04 \mathrm{~g} / \mathrm{L}$ on the day of birth to $20.9 \mathrm{~g} / \mathrm{L}$ on the second day after colostrum intake and then it decreased to $8.37 \mathrm{~g} / \mathrm{L}$ at 16th day of age (Barta, 1993). Pregnant cows supplemented with Se increased concentrations of $\mathrm{IgG}$ in colostrum and plasma (Awadeh et al., 1998; Boland et al., 2005; Rodinova et al., 2008). Rock et al. (2001) supplemented ewes with Se from 56 day of gestation until lambing and noted increased $\mathrm{IgG}$ absorption in their lambs. Based on this study, it might be considered that Se supplementation to ewes in late pregnancy can provide protection from diarrhea that causes deaths among lambs during neonatal period, which will have a positive effect on health and welfare due to increased colostrum Se concentration and, thus, lamb serum IgG concentration. It might be suggested that increasing Se concentration in the colostrum to be consumed by lambs immediately after birth strengthens the immune system.

\section{Conclusions}

Prepartum and postpartum organic Se supplementation is essential to maintain selenium and immunoglobulin $\mathrm{G}$ concentrations during late pregnancy in ewes and their lambs.

\section{Acknowledgments}

This study was supported by Yuzuncu Yil University Scientific Research Project Funding (YYU-BAP/2011-ZFB007).

\section{References}

Abdelrahman, M. M. and Kincaid, R. L. 1995. Effect of selenium supplementation of cows on maternal transfer of selenium to fetal and newborn calves. Journal of Dairy Science 78:625-630.

Alonso, M. J. L.; Barrera, A. B.; Cocho de Juan, J. A.; Bermúdez, J. M. F. and Barrera, P. B. 2005. Selenium levels in related biological samples: Human placenta, maternal and umbilical cord blood, hair and nails. Journal of Trace Elements in Medicine and Biology 19:49-54

ANKOM. 2008. ANKOM Technology Method AOCS Official Procedure Am 5-04. Rapid determination of oil/fat utilizing high temperature solvent extraction. Available at: $<$ https://www.ankom. com/sites/default/files/document-files/CrudeFat_0504_013009_0.pdf $>$. Accessed on: Jan. 30, 2009.

AOAC. Association of Official Analytical Chemists. 1990. Official methods of analysis. 15th ed. Arlington, VA.

Arthur, J. R.; Nicol, F. and Beckett, G. J. 1992. The role of selenium in thyroid hormone metabolism and effects of selenium deficiency on thyroid hormone and iodine metabolism. Biological Trace Element Research 34:321-325.
Awadeh, F. T.; Abdelrahman, M. M.; Kincaid, R. L. and Finley, J. W. 1998. Effects of selenium supplements on the distribution of selenium among serum proteins in cattle. Journal of Dairy Science 81:1089-1094.

Awawdeh, M. S. and Talafha, A. Q. 2015. Blood and milk status of vitamin E, vitamin A and selenium in nursing Awass ewes injected with vitamin E and selenium. Acta Agriculturae Scandinavica, Section A 65:176-182.

Barta, O. 1993. Radial immune diffusion quantitative determination of immunoglobulins and C3. Monographs in Animal Immunology 2:3-14.

Beckett, G. J.; MacDougall, D. A.; Nicol, F. and Arthur, J. R. 1989. Inhibition of type I and II iodothyronine deiodinase activity in rat liver, kidney and brain produced by selenium deficiency. Biochemical Journal 259:887-892.

Boland, T. M.; Brophy, P. O.; Callan, J. J.; Quinna, P. J.; Nowakowski, P. and Crosby, T. F. 2005. The effects of mineral supplementation to ewes in late pregnancy on colostrum yield and immunoglobulin $\mathrm{G}$ absorption in their lambs. Livestock Production Science 97:141-150.

Coggins, V. L. 2006. Selenium supplementation, parasite treatment, and management of bighorn sheep at Lostine River, Oregon. Bienn Symp North Wild Sheep Goat Counc 15:98-106.

Cuesta, P. A.; McDowell, L. R.; Kunkle, W. E.; Wilkinson, N. S. and Martin, F. G. 1994. Effects of high doses of selenium and vitamin E injected into cows prepartum on milk and serum concentrations of these nutrients. International Journal Animal Science 9:275-278.

Cuesta, P. A.; McDowella, T. L. R.; Kunkle, W. E., Wilkinson, N. S. and Martin, F. G. 1995. Effects of high-dose prepartum injections of Se and vitamin $\mathrm{E}$ on milk and serum concentrations in ewes. Small Ruminant Research 18:99-103.

Davis, P. A.; McDowell, L. R.; Wilkinson, N. S.; Buergelt, C. D.; Van Alstyne, R.; Weldon, R. N. and Marshall, T. T. 2006. Effects of selenium levels in ewe diets on selenium in milk and plasma and tissue selenium concentrations of lambs. Small Ruminant Research 65:14-23.

De Toledo, L. R. A. and Perry, T. W. 1985. Distribution of supplemental selenium in the serum, hair, colostrum and fetus of parturient dairy cows. Journal of Dairy Science 68:3249-3254.

Donald, G. E.; Langlands, J. P.; Bowles, J. E. and Smith, A. J. 1994. Subclinical selenium insufficiency. 6. Thermoregulatory ability of perinatal lambs born to ewes supplemented with selenium and iodine. Australian Journal of Experimental Agriculture 34:19-24.

Fisher, G. E. J. 2008. Micronutrients and animal nutrition and the link between the application of micronutrients to crops and animal health. Turkish Journal of Agriculture and Forestry 32:221-233.

Gabryszuk, M. and Klewiec, J. 2002. Effect of injecting 2- and 3-yearold ewes with selenium and selenium vitamin $\mathrm{E}$ on reproduction and rearing of lambs. Small Ruminant Research 43:127-132.

Gunter, S. A. and Beck, P. A.; Hallford, D. M. 2013. Effects of supplementary selenium source on the blood parameters in beef cows and their nursing calves. Biological Trace Element Research 152:204-211.

Hefnawy, A. E.; López-Arellano, A. E.; Revilla-Vázquez, R.; RamírezBribiesca, A. and Tórtora-Pérez, J. L. 2007. Interrelationship between fetal and maternal selenium concentrations in small ruminants. Small Ruminant Research 73:174-180.

Hefnawy, A. E.; Lopez-Arellano, R.; Revilla-Vasquez, A.; RamirezBribiesca, E. and Tortora-Perez, J. L. 2008. Effect of pre and postpartum selenium supplementation in sheep. Journal of Animal Veterinary Advances 7:61-67.

Hefnawy, A. E. and Tortoro-Perez, J. L. 2010. The importance of selenium and the effects of its deficiency in animal health. Small Ruminant Research 89:185-192. 
Hefnawy, A. E.; Youssef, S.; Aguilera, P. V.; Rodriguez, C. V. and Tortora Perez, J. L. 2014. The relationship between selenium and T3 in selenium supplemented and nonsupplemented ewes and their lambs. Veterinary Medicine International 2014:1-6.

Hemingway, R. G. 2003. The influences of dietary intakes and supplementation with selenium and vitamin $\mathrm{E}$ on reproduction diseases and reproductive efficiency in cattle and sheep. Veterinary Research Communication 27:159-174.

Humann-Ziehank, E.; Tegtmeyer, P. C.; Seelig, B.; Roehrig, P. and Ganter, M. 2013. Variation of serum selenium concentrations in German sheep flocks and implications for herd health management consultancy. Acta Veterinaria Scandinavica 55:82-83.

Jalilian, M. T.; Moeini, M. M. and Karkodi, K. 2012. Effect of selenium and vitamin $\mathrm{E}$ supplementation during late pregnancy on colostrum and plasma $\mathrm{Se}, \mathrm{Cu}, \mathrm{Zn}$ and $\mathrm{Fe}$ concentrations of fat tail Sanjabi ewes and their lamb. Acta Agriculturae Slovenica 100:123-129.

Kachuca, R.; Moeini, M. and Sauri, M. 2013. Effects of organic and inorganic selenium supplementation during late pregnancy on colostrum and serum Se status, performance and passive immunity in Merghoz goats. Animal Production Science 54:1016-1022.

Karadaş, F. 2014. Scientific data on selenium status in Turkey. Agricultural Sciences 5:87-93.

Karimi-Poor, M.; Tabatabaie, S. N.; Zamani, F.; Pirestani, A. and Bahrami, Y. 2011. Investigation of selenium concentration of sheep's diet, blood and milk in different regions from a central state of Iran. Annals of Biological Research 2:51-61.

Karren, B. J.; Thorson, J. F.; Cavinder, C. A.; Hammer, C. F. and Coverdale, J. A. 2010. Effect of selenium supplementation and plane of nutrition on mares and their foals: Selenium concentrations and glutathione peroxidase. Journal of Animal Science 88:991-997.

Kincaid, R. L. and Hodgson, A. S. 1989. Relationship of selenium concentrations in blood of calves to blood selenium of the dam and supplemental selenium. Journal of Dairy Science 72:259-266.

Kolb, E. and Seehawer, J. 2001. The importance of selenium availability and deficiency in cattle - The prevention of deficiency. Tierarztliche Umschau 56:263-269.

Konečný, R.; Hasoňová, L.; Trávníček, J.; Samková, E.; Hladký, J. and Kř́žová, Z. 2015. Effect of organic selenium and rodine supplementation on selenium and thyroid hormones status of lactating ewes and lambs. Acta Veterinaria 65:477-487.

Kozat, S.; Gündüz, H.; Değer, Y.; Mert, N.; Yörük, İ. H. and Sel, T. 2007. Studies on serum $\alpha$-tocopherol, selenium levels and catalase activities in lambs with white muscle disease. Bulletin of the Veterinary Institute in Pulawy 51:281-284.

Kurt, D.; Denli, O.; Kanay, Z.; Güzel, C. and Ceylan, K. 2001. An investigation of the copper $(\mathrm{Cu})$, zinc $(\mathrm{Zn})$ and selenium $(\mathrm{Se})$ levels of blood serum and the cu and zn levels of wool of Akkaraman ewes in the Diyarbakır region. Turk Journal of Veterinary Animal Science 25:431-436.

Langlands, J. P.; Donald, G. E., Bowles, J. E. and Smith, A. J. 1991a. Subclinical selenium insufficiency 1 . Selenium status and the response in live weight and wool production of grazing ewes supplemented with selenium. Australian Journal of Experimental Agriculture 31:25-31.

Langlands, J. P.; Donald, G. E.; Bowles, J. E. and Smith, A. J. 1991 b. Subclinical selenium insufficiency 2 . The response in reproductive performance of grazing ewes supplemented with selenium. Australian Journal of Experimental Agriculture 31:33-35.

Lyons, M. P.; Papazyan, T. T. and Surai, P. F. 2007. Selenium in food chain and animal nutrition: Lessons from Nature. Asian-Australian Journal of Animal Science 20:1135-1155.

Moeini, M. M.; Kiani, A.; Karami, H. and Mikaeili, E. 2011. The Effect of selenium administration on the selenium, copper, iron and zinc status of pregnant heifers and their newborn calves. Journal of Agricultural Science and Technology 13:53-59.

Nazifi, S.; Saeb, M.; Abangah, E. and Karimi, T. 2008. Studies on the relationship between thyroid hormones and some trace elements in the blood serum of Iranian fat-tailed sheep. Veterinarski Arhiv 78:159-165.

Norheim, G. and Haugen, A. 1986. Precise determination of selenium in tissues using automated wet digestion and an automated hydride generator-atomic absorption spectroscopy system. Acta Pharmacologica et Toxicologica 59:610-612.

Norton, S. A. and McCarthy, F. D. 1986. Use of injectable vitamin E and selenium-vitamin $\mathrm{E}$ emulsion in ewes and suckling lambs to prevent nutritional muscular dystrophy. Journal of Animal Science 62:497-508

NRC - National Research Council. 2007. Nutrient requirements of small ruminants (sheep, goats, cervids and new world camelids). National Research Council National Academy Press, Washington, DC

Øvernes, G.; Moksnes, K.; Froslie, A.; Gunnar, J. G. and Flaat, J. 1985. The effect of different levels of selenium in mineral mixtures and salt licks on selenium status in sheep. Acta Veterinaria Scandinavica 26:405-416.

Öncüler, A.; Tükenmez, İ. and Bakioğlu, T. 1996. Determination of regional and reasonal nutritional selenium status of cattle and sheep by neutron activation analysis. Journal of the Faculty of Veterinary Medicine, Kafkas University 2:43-48.

Quinn, F. A. 2005. Architect 12000 and 12000SR analyzers. p.406-411. In: Immunoassay handbook. Wild, D., ed. 3rd ed. Elsevier, Amsterdam.

Phipps, R. H.; Grandison, A. S.; Jones, A. K.; Juniper, D. T.; RamosMorales E. and Bertin, G. 2008. Selenium supplementation of lactating dairy cows: Effects on milk production and total selenium content and speciationin blood, milk and cheese. Animal 2:1610-1618

P1larczyk, B.; Balicka-Ramisz, A.; Ramisz, A.; Vovk, S.; Major, D.; Jastrzebski, G. and Cisek, A. 2004. Effect on selenium supplementation on serum Se levels and selected of performance parameters in cows, pigs and sheep. Folia University Agricultural Stetin Zootechnica 235:53-58.

Rock, M. J.; Kincaid, R.L. and Carstens, G. F. 2001. Effects of prenatal source and level of dietary selenium on passive immunity and thermometabolism in new born lambs. Small Ruminant Research 40:129-138.

Rodinova, H.; Kroupova, V.; Travnicek, V., Stakova, M. and Pisek, L. 2008. Dynamics of IgG in the blood serum of sheep with different selenium intake. Veterinarni Medicina 53:260-265.

Rowntree, J. E.; Hill, G. H.; Hawkins, D. R.; Link, J. E.; Rincker, M. J.; Bednar, G. W. and Kreft Jr, R. A. 2004. Effect of selenium on selenoprotein activity and thyroid hormone metabolism in beef and dairy cows and calves. Journal of Animal Science 82:2995-3005.

Rutigliano, H. M.; Cerri, R. L. A.; Lima, F. S.; Vettorato, L. F.; Araujo, D. B. and Hillegass, J. 2006. Effects of source of supplemental selenium on health and immune status of periparturient dairy cows. Journal of Dairy Science 89(Suppl.1):165.

Slavik, P.; Illek, J.; Brix, M.; Hlavicova, J.; Rajmon, R. and Jilek, F. 2008. Influence of organic versus inorganic dietary selenium supplementation on the concentration of selenium in colostrums, milk and blood of beef cows. Acta Veterinaria Scandinavica 50:1-6.

Sordillo, L. M. 2013. Selenium-dependent regulation of oxidative stress and immunity in periparturient dairy cattle. Hindawi Publishing Corporation. Veterinary Medicine International 2013:8. 
Spears, J. W. 2011. Selenium deficiency and its prevention in grazing ruminants. Salt and Trace Minerals for Livestock. Available at: $<$ http://www.saltinstitute.org/wp-content/uploads/2013/05/4thqtr-2011.pdf>. Accessed on: Oct. 20, 2016.

Stewart, W. C.; Bobe, G.; Pirelli, G. J.; Mosher, W. D. and Hall, J. A. 2012. Organic and inorganic selenium: III. Ewe and progeny performance. Journal of Animal Science 90:4536-4543.

Van Soest, P. J.; Robertson, J. B. and Lewis, B. A. 1991. Methods for dietary fiber, neutral detergent fiber, and nonstarch polysaccharides in relation to animal nutrition. Journal of Dairy Science 74:3583-3597.
Waldner, C.; Campbell, J.; Jim, G. E.; Guichon, P. T. and Booker, C. 1998. Comparison of 3 methods of selenium assessment in cattle. Canadian Veterinary Journal 39:225-231.

Wichtel, J. J.; Thompson, K. G.; Craigie, A. L. and Williamson, N. B. 1996. Effects of selenium and iodine supplementation on the growth rate, mohair production, and thyroid status of Angora goat kids. New Zealand Journal of Agricultural Research 39:111-115.

Wuryastuti, H.; Stowe, H. D.; Bull, R.W. and Miller, E. R. 1993. Effects of vitamin $\mathrm{E}$ and selenium on immune responses of peripheral blood, colostrum, and milk leukocytes of sows. Journal of Animal Science 71:2464-2472. 